International Journal of Emerging Trends in Engineering Research

Available Online at http://www.warse.org/IJETER/static/pdf/file/ijeter77862020.pdf

https://doi.org/10.30534/ijeter/2020/77862020

\title{
Mathematical Modeling of Determining the Productivity of Mobile Complexes in Exercise of Inclined Connecting Accessories
}

\author{
AnnakulovTulkin, ShamsievRaxim, KuvandikovOybek \\ Tashkent state technical university named after Islam Karimov, University street 2, Tashkent, 100095 Uzbekistan \\ a.tulkin1275@yandex.ru
}

\begin{abstract}
This article provides a methodology for determining the working time and productivity of mobile excavatorcrushing and conveyor complexes in the development of an inclined exit ledge. At different bottom heights, the fill factor of the excavator bucket is determined. A mathematical model has been developed to determine the area of the excavator digging segment with the establishment of the chip thickness.
\end{abstract}

Keywords: excavator-crushing complex, excavator productivity, inclined exit bench, working time, double integral.

\section{INTRODUCTION}

Currently, in the development of overburden of coal deposits and deposits of carbonate rocks, uniform instrength and multi-strength with the content of weak differences of up to $30 \%$, cyclic-flow technology (CFT) using mobile crushing, reloading and conveyor complexes (MCRCC) is used [1,2,3,10,12].

According to this technology, as in Figure 1, the rock is loaded by an excavator in a mobile crusher through a hopper-feeder. The rock from the crushing plant is transferred to a mobile conveyor-reloader and further to the downhole conveyor. Using a mobile conveyor reloader allows you to reduce the frequent movement of the downhole conveyor and place them at a considerable distance from the bottom $[4,5,10,12]$.

Mobile crushing and reloading plants are used in various technological schemes, are located in the face between the excavatorand the face conveyor and move along the front of the work as the excavator moves.

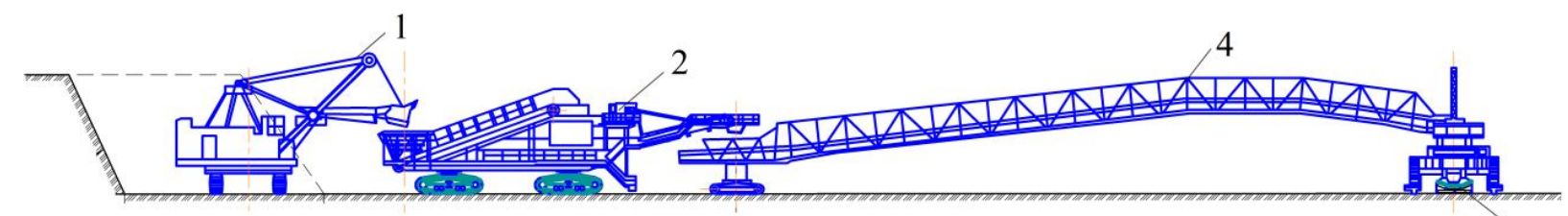

Figure 1: The technological scheme of working out the ledge using a mobile excavator and conveyor complex:1 - excavator; 2 - mobile crushing plant; 3 - downhole conveyor belt; 4 - mobile conveyor loader

Let us consider the technological scheme for working out benches with longitudinal runs by the MCRCC complex with a lateral location of the downhole conveyor and the presence of a mobile interstage loading crane with sequential mining operations at two horizons (see Figure 2).According to this technological scheme, the MCRCCsystem works on two horizons. In this case, the downhole conveyor is installed on the upper ledge. Excavator-mobile crusher - an interstagereloader works first on the lower ledge, and then on the upper ledge with two runs. After that, the downhole conveyor moves along the front of the excavator $[5,9,11]$.

The technological processes during mining operations on the exit ledge using MCRCC are shown in the table. 1.

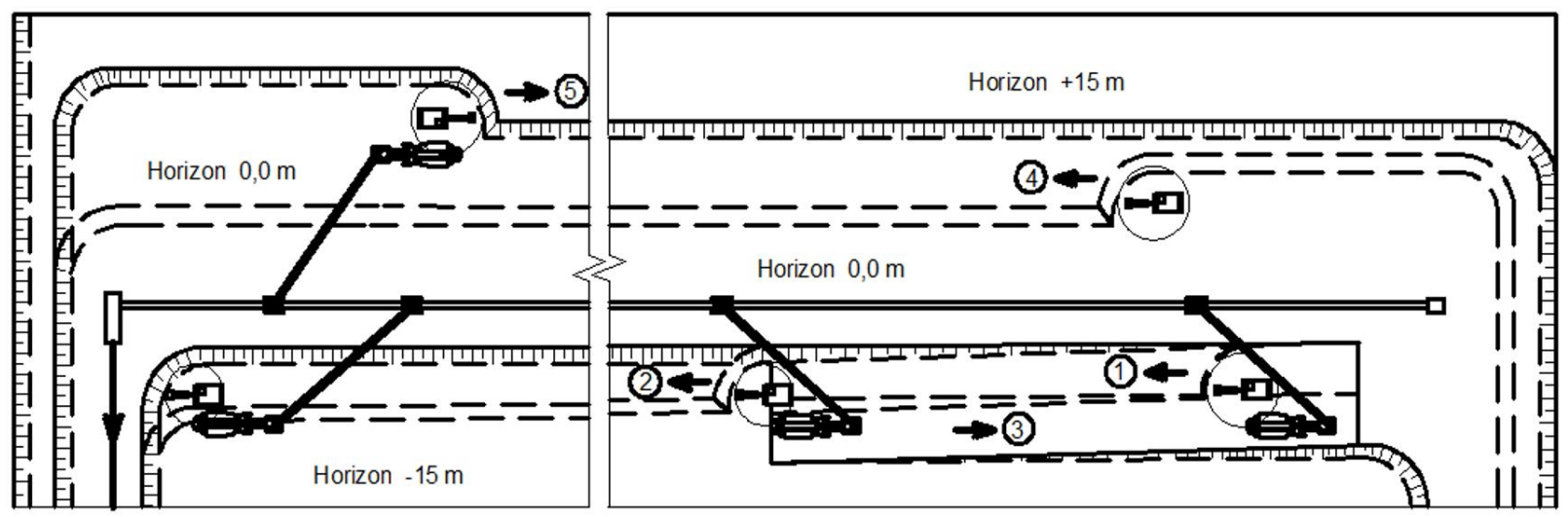

Figure 2: The technological scheme of working out benches using mobile systems with sequential mining operations at two horizons [11] 
Table 1:Technological processes of mining with a ramp using MCRCC

\begin{tabular}{|c|c|c|}
\hline $\begin{array}{l}\text { Process } \\
\text { number }\end{array}$ & Process name & $\begin{array}{c}\text { Process } \\
\text { Brief } \\
\end{array}$ \\
\hline 1 & $\begin{array}{l}\text { Development of the first } \\
\text { inclined exit ledge with the } \\
\text { descent to the lower horizon }\end{array}$ & $\mathrm{R}_{\mathrm{EL}(1)}$ \\
\hline 2 & $\begin{array}{l}\text { Development of the left } \\
\text { flank of the main lower } \\
\text { ledge }\end{array}$ & $\mathrm{R}_{\mathrm{ML}(1 \mathrm{~L})}$ \\
\hline 3 & $\begin{array}{l}\text { U-turn and reverse } \\
\text { movement of the complex } \\
\text { on the left flank of the lower } \\
\text { ledge }\end{array}$ & $\mathrm{D}_{\mathrm{T}}+\mathrm{D}_{\mathrm{ML}(1 \mathrm{~L})}$ \\
\hline 4 & $\begin{array}{l}\text { Development of a second } \\
\text { inclined exit ledge }\end{array}$ & $\mathrm{R}_{\mathrm{EL}(2)}$ \\
\hline 5 & $\begin{array}{l}\text { U-turn and reverse } \\
\text { movement of the complex } \\
\text { along the right flank of the } \\
\text { lower ledge }\end{array}$ & $\mathrm{D}_{\mathrm{T}}+\mathrm{D}_{\mathrm{ML}(1 \mathrm{R})}$ \\
\hline 6 & $\begin{array}{l}\text { Moving the complex along } \\
\text { the first inclined exit ledge } \\
\text { to the upper horizon }\end{array}$ & $\mathrm{D}_{\mathrm{EL}(1)}$ \\
\hline 7 & $\begin{array}{l}\text { Moving the complex to its } \\
\text { starting position on the } \\
\text { upper ledge }\end{array}$ & $\mathrm{D}_{\mathrm{SP}(2)}$ \\
\hline 8 & $\begin{array}{l}\text { Development of the first } \\
\text { entry of the upper ledge }\end{array}$ & $\mathrm{R}_{\mathrm{ML}(1 \mathrm{E})}$ \\
\hline 9 & $\begin{array}{l}\text { Development of the second } \\
\text { entry of the upper ledge }\end{array}$ & $\mathrm{R}_{\mathrm{ML}(2 \mathrm{E})}$ \\
\hline 10 & $\begin{array}{l}\text { Movement of the complex } \\
\text { by turning to the first } \\
\text { starting position }\end{array}$ & $\mathrm{D}_{\mathrm{SP}(1)}$ \\
\hline 11 & $\begin{array}{l}\text { Downhole } \\
\text { movement }\end{array}$ & $\mathrm{D}_{\mathrm{C}}$ \\
\hline
\end{tabular}

According to the table. 1, combining the relevant processes, we determine the full cycle of MCRCC in the following form [5]:

$$
\begin{gathered}
1 \mathrm{CYCLE}=\left[\mathrm{R}_{\mathrm{EL}(1)}+\mathrm{R}_{\mathrm{EL}(2)}\right]+\left[\mathrm{R}_{\mathrm{ML}(1 \mathrm{~L})}+\mathrm{R}_{\mathrm{ML}(1 \mathrm{E})}+\right. \\
\left.\mathrm{R}_{\mathrm{ML}(2 \mathrm{E})}\right]+\left[\mathrm{D}_{\mathrm{T}}+\mathrm{D}_{\mathrm{ML}(1 \mathrm{~L})}+\mathrm{D}_{\mathrm{T}}+\mathrm{D}_{\mathrm{ML}(1 \mathrm{R})}+\mathrm{D}_{\mathrm{EL}(1)}+\right. \\
\left.\mathrm{D}_{\mathrm{SP}(2)}+\mathrm{D}_{\mathrm{SP}(1)}+\mathrm{D}_{\mathrm{C}}\right]=2 \mathrm{R}_{\mathrm{EL}}+\mathrm{R}_{\mathrm{ML}(1 \mathrm{~L})}+2 \mathrm{R}_{\mathrm{ML}(2)}+ \\
2 \mathrm{D}_{\mathrm{T}}+\mathrm{D}_{\mathrm{ML}(1)}+\mathrm{D}_{\mathrm{EL}(1)}+2 \mathrm{D}_{\mathrm{SP}}+\mathrm{D}_{\mathrm{C}}(1)
\end{gathered}
$$

The time of one cycle of working out of two benches with the use of MCRCC is [5]:

$$
\begin{aligned}
& \mathrm{T}_{\mathrm{CYCLE}}=2 \mathrm{~T}_{\mathrm{R} . \mathrm{EL}}+\mathrm{T}_{\mathrm{R} . \mathrm{ML}(1 \mathrm{~L})}+2 \mathrm{~T}_{\mathrm{R} . \mathrm{ML}(2)}+2 \mathrm{~T}_{\mathrm{D} . \mathrm{T}}+ \\
& \mathrm{T}_{\mathrm{D} . \mathrm{ML}(1)}+\mathrm{T}_{\mathrm{D} . \mathrm{EL}(1)}+2 \mathrm{~T}_{\text {D.SP }}++\mathrm{T}_{\mathrm{D} . \mathrm{C}}, \mathrm{h}
\end{aligned}
$$

2. METHODOLOGY FOR DETERMINING THE WORKING TIME OF AN INCLINED EXIT LEDGE AND THE PRODUCTIVITY OF THE MCRCC COMPLEX

When calculating the operational productivity and operating time of the complex according to the technological scheme for the development of rocks with an end position of the MCRCC and the presence of a mobile interstage loading crane with sequential mining at two horizons, all downtimes of the excavator must be taken into account.

We calculate the working time of the exit ledge and determine the average operational productivity of the MCRCC complex in the conditions of the Angrencoal mine [10].

Initial data for the calculation: Existing technological parameters of the face of the Angrensky section and the initial data are summarized in the table. 2 , and the technical characteristics of the excavator, crusher and mobile interstage conveyor loader - in the table 3.-5.

Table 2: Existing technological parameters of the face

\begin{tabular}{|l|c|c|c|}
\hline $\begin{array}{c}\text { Name of technological } \\
\text { parameters }\end{array}$ & Symbol & $\begin{array}{c}\text { Measu- } \\
\text { rement }\end{array}$ & $\begin{array}{c}\text { Quan- } \\
\text { tity }\end{array}$ \\
\hline Ledge height & $\mathrm{H}_{\mathrm{L}}$ & $\mathrm{m}$ & 15 \\
\hline Ledge angle & $\alpha$ & grad. & 70 \\
\hline Excavation trench width & $\mathrm{B}_{\mathrm{W}}$ & $\mathrm{m}$ & $22,5-25$ \\
\hline $\begin{array}{l}\text { Distance from the bottom } \\
\text { edge of the ledge to the } \\
\text { crusher transport line }\end{array}$ & $\mathrm{c}_{1}$ & $\mathrm{~m}$ & $\begin{array}{c}1,2- \\
4,05\end{array}$ \\
\hline Installation width & $\mathrm{B}_{\mathrm{I} . \mathrm{W}}$ & $\mathrm{m}$ & $20-90$ \\
\hline $\begin{array}{l}\text { Width from conveyor } \\
\text { axis to the upper edge of } \\
\text { the lower ledge }\end{array}$ & $\mathrm{B}_{\mathrm{L} . \mathrm{L} .}$ & $\mathrm{m}$ & 10 \\
\hline Platform width & $\mathrm{B}_{\mathrm{P} . \mathrm{W}}$ & $\mathrm{m}$ & $60-130$ \\
\hline $\begin{array}{l}\text { Unloading angle of the } \\
\text { excavator }\end{array}$ & $\beta$ & grad. & $60-180$ \\
\hline \multicolumn{2}{|c|}{ Soil type: sandstones and pebbles in clay cement } \\
\hline Density & $\gamma$ & $\mathrm{t} / \mathrm{m}^{3}$ & $1,9-2,3$ \\
\hline Coefficient of loosening & $\mathrm{k}_{\mathrm{L}}$ & & $1,1-1,4$ \\
\hline
\end{tabular}

Table 3: Technical characteristics of the excavator EKG-15M

\begin{tabular}{|l|c|c|c|}
\hline \multicolumn{1}{|c|}{$\begin{array}{c}\text { Basic operating } \\
\text { parameters }\end{array}$} & $\begin{array}{c}\text { Sym- } \\
\text { bol }\end{array}$ & $\begin{array}{c}\text { Measure- } \\
\text { ment }\end{array}$ & $\begin{array}{c}\text { Quan- } \\
\text { tity }\end{array}$ \\
\hline Bucket capacity & $\mathrm{V}_{\mathrm{b}}$ & $\mathrm{m}^{3}$ & 16,5 \\
\hline $\begin{array}{l}\text { Standing level } \\
\text { scooping radius } \\
\text { (maximum) }\end{array}$ & $\mathrm{R}_{\mathrm{CT}}^{\max }$ & $\mathrm{m}$ & 15,6 \\
\hline $\begin{array}{l}\text { Standing level } \\
\text { scooping radius } \\
\text { (minimum) }\end{array}$ & $\mathrm{R}_{\mathrm{CT}}^{\min }$ & $\mathrm{m}$ & 10,1 \\
\hline $\begin{array}{l}\text { The greatest radius of } \\
\text { scooping }\end{array}$ & $\mathrm{R}_{\mathrm{Y}}^{\max }$ & $\mathrm{m}$ & 22,6 \\
\hline Greatest heights & $\mathrm{H}_{\mathrm{G}}^{\max }$ & $\mathrm{m}$ & 15,8 \\
\hline $\begin{array}{l}\text { Highest discharge } \\
\text { height }\end{array}$ & $\mathrm{H}_{\mathrm{B} . \mathrm{B}}^{\max }$ & $\mathrm{m}$ & 9,9 \\
\hline $\begin{array}{l}\text { The largest radius of } \\
\text { unloading }\end{array}$ & $\mathrm{R}_{\mathrm{U}}^{\max }$ & $\mathrm{m}$ & 19,5 \\
\hline Cycle duration (at 900$)$ & $\mathrm{t}_{\mathrm{c}}$ & $\mathrm{s} / \mathrm{min}$ & $28 / 0,46$ \\
\hline Excavator head height & $\mathrm{H}_{\mathrm{head}}$ & $\mathrm{m}$ & 18,7 \\
\hline $\begin{array}{l}\text { Excavator height on } \\
\text { biped rack }\end{array}$ & $\mathrm{H}_{\mathrm{biped}}$ & $\mathrm{m}$ & 15, \\
\hline Travelspeed & $\mathrm{V}_{\text {travel }}$ & $\mathrm{km} / \mathrm{h}$ & $\begin{array}{c}0,7 \\
0\end{array}$ \\
\hline
\end{tabular}

Table 4: Technical specifications of mobile crusher

\begin{tabular}{|l|c|c|c|}
\hline $\begin{array}{c}\text { Basicoperatingpara } \\
\text { meters }\end{array}$ & $\begin{array}{c}\text { Sym- } \\
\text { bol }\end{array}$ & $\begin{array}{c}\text { Measure- } \\
\text { ment }\end{array}$ & $\begin{array}{c}\text { Quan- } \\
\text { tity }\end{array}$ \\
\hline $\begin{array}{l}\text { Estimated } \\
\text { productivity }\end{array}$ & $\mathrm{P}_{\mathrm{E}}$ & $\mathrm{t} / \mathrm{h}$ & 4000 \\
\hline Crushedrockfortress & $\mathrm{f}$ & & $8-12$ \\
\hline Hoppercapacity & $\mathrm{V}_{\mathrm{H}}$ & $\mathrm{m}^{3}$ & 50 \\
\hline
\end{tabular}


AnnakulovTulkinet al.,International Journal of Emerging Trends in Engineering Research, 8(6), June 2020,2695 - 2700

\begin{tabular}{|l|c|c|c|}
\hline Hopper height & $\mathrm{H}_{\mathrm{H}}$ & $\mathrm{m}$ & 8 \\
\hline Boom length & $\mathrm{L}_{\mathrm{B} . \mathrm{L}}$ & $\mathrm{m}$ & $18-25$ \\
\hline Totallengthofcrusher & $\mathrm{L}_{\mathrm{C}}$ & $\mathrm{m}$ & 44 \\
\hline Crusher width & $\mathrm{B}_{\mathrm{C}}$ & $\mathrm{m}$ & 12,8 \\
\hline $\begin{array}{l}\text { The size of the loaded material: } 1100 \mathrm{~mm} \text { (5\% of the } \\
\text { total mass), over } 300 \mathrm{~mm}(20 \% \text { of the total mass), up to } \\
300 \mathrm{~mm} \text { (75\% of the total mass) }\end{array}$ \\
$\begin{array}{l}\text { Final material } \\
\text { fineness }\end{array}$ & $\mathrm{mm}$ & $0-300$ \\
\hline
\end{tabular}

\begin{tabular}{|l|c|c|c|}
\hline $\begin{array}{l}\text { The total length of the } \\
\text { rece-iving and unloading } \\
\text { boom }\end{array}$ & $\mathrm{L}_{\mathrm{b}}$ & $\mathrm{m}$ & $72-82$ \\
\hline Tiltboom & & grad. & \pm 16 \\
\hline Tippingboom & & grad. & \pm 16 \\
\hline TravelSpeed (Maximum) & $\mathrm{V}_{\mathrm{nep}}$ & $\mathrm{m} / \mathrm{min}$ & $8-10$ \\
\hline Minimumturningradius & $\mathrm{R}_{\mathrm{p}}^{\min }$ & $\mathrm{m}$ & $10-12$ \\
\hline Allowedtiltwhenmoving & $\mathrm{i}_{\mathrm{a}}$ & & $1: 10$ \\
\hline $\begin{array}{l}\text { Permissibletiltduringoper } \\
\text { ation }\end{array}$ & $\mathrm{i}_{\mathrm{p}}$ & & $1: 20$ \\
\hline
\end{tabular}

Table 5: Technical specifications of mobile interstage conveyor loader

\begin{tabular}{|l|c|c|c|}
\hline $\begin{array}{c}\text { Basicoperatingparamet } \\
\text { ers }\end{array}$ & $\begin{array}{c}\text { Sym- } \\
\text { bol }\end{array}$ & $\begin{array}{c}\text { Measure- } \\
\text { ment }\end{array}$ & $\begin{array}{c}\text { Quan- } \\
\text { tity }\end{array}$ \\
\hline EstimatedProductivity & $\mathrm{P}_{\mathrm{E}}$ & $\mathrm{t} / \mathrm{h}$ & 4000 \\
\hline Feedsize & $\mathrm{d}$ & $\mathrm{mm}$ & $0-300$ \\
\hline $\begin{array}{l}\text { The height of the worked } \\
\text { benches }\end{array}$ & $\mathrm{H}_{\mathrm{h}}$ & $\mathrm{m}$ & 15 \\
\hline
\end{tabular}

When working out an exit ledge with the use of MCRCC, up to $5 \%$ slope is allowed, which has the form shown in Figure 3.The permissible angle of the inclination of the ramp is equal to a ratio of 1:20. With a 5\% slope, this angle will be $2.86^{\circ}$.

Define the length of the ramp on the segment $\mathrm{AB}$ with the height of the ledge $15 \mathrm{~m}: \mathrm{AB}=\mathrm{BC} / \sin 2,86^{\circ}=300,6 \mathrm{~m}$.

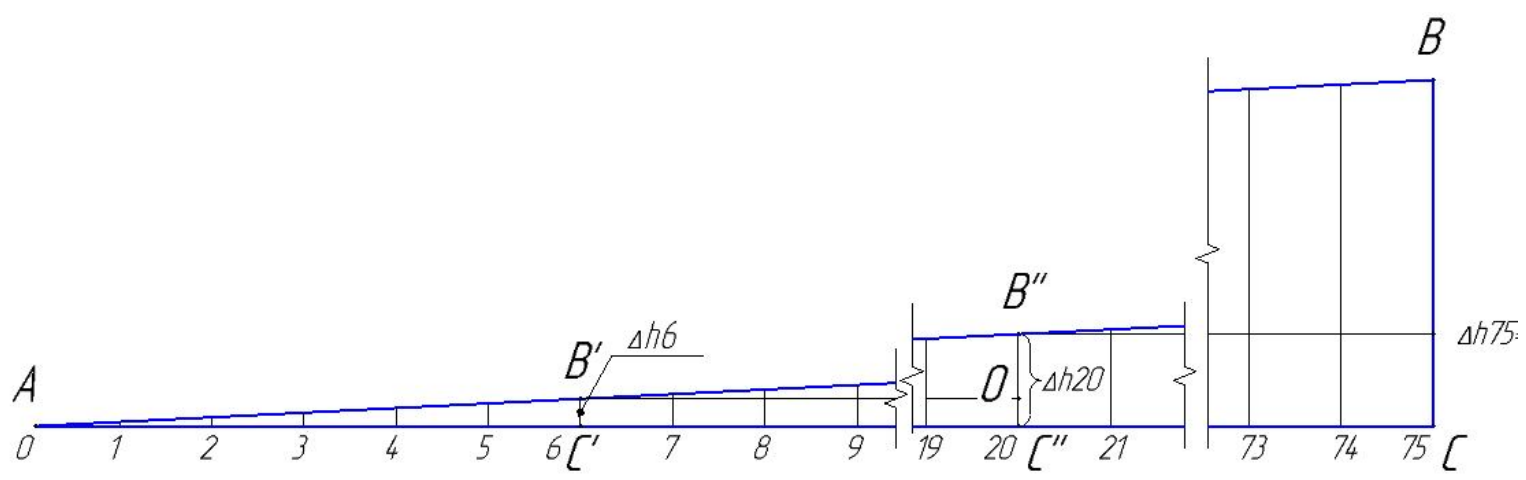

Figure 3: The scheme of the exit ledge with the division into 75 subunits of length, each equal to one excavator, moving

Taking into account the movement of the excavator from one parking lot to the next with $\mathrm{L}_{\text {moving }}=4 \mathrm{~m}$, the number of subunits will be $300,6 \mathrm{~m} / 4 \mathrm{~m}=75$. This means that the excavator, working on the exit ledge, moves 75 times (Fig. 3).

In the first part of the block, the excavator will not be able to load the crushing plant due to the non-filling of its bucket. In this regard, under the conditions of the effective operation of the excavator, we determine the minimum digging height.

Under the conditions of full filling of the bucket with a known thickness of the removed chips, we determine the length of the scooping arc:

$$
l_{\text {d.s. }}=\frac{V_{b} \mathrm{k}_{f}}{\mathrm{~B}_{b} \mathrm{C}_{\max } K_{L}}, \mathrm{~m}
$$

where $\mathrm{B}_{b}$ - is the width of the excavator bucket, $\mathrm{m}$;

$\mathrm{C}_{\max }$ - the thickness of the removed chips, $\mathrm{m}$;

$k_{f}$ - bucket fill factor;

The thickness of the removed chips is determined by calculations, taking into account the digging force of the excavator and the specific resistance to digging the rock [6]:

$$
\mathrm{C}_{\text {max }}=\frac{\mathrm{P}_{t}}{k_{S} \mathrm{~B}_{b}}, \mathrm{~m}
$$

where $\mathrm{P}_{t}$ - is the force on the teeth of the bucket of the excavator, $\mathrm{N}$;

$k_{S}$ - specific resistance to digging rocks, $\mathrm{N} / \mathrm{m}^{2}$.

Digging resistivity for rocks of category III is accepted for excavator $_{F}=160 \div 280 \mathrm{\kappa Pa}=(16 \div 28)$.

$10^{4}, \mathrm{~N} / \mathrm{m}^{2}[7]$.

The force on the teeth of the excavator bucket for specific conditions of the face is determined by the formula [8]:

$$
\mathrm{P}_{t . b}=\frac{N_{r} \cdot l_{h . c}+G_{(b+b r)} \cdot l_{h . b}+\mathrm{G}_{\mathrm{p}} \cdot l_{h . h}}{l_{h}}, \mathrm{~N}
$$

where $N_{r}$ - resistance to rock digging, N;

$G_{(b+b r)}$ - the weight of the bucket with the breed, N;

$G_{h}$-handle the weight, $\mathrm{N}$;

$l_{h . c}, l_{h . b}, l_{h . h}$ - respectively, the length of the handle from the pressure shaft to the bottom contact, to the center of gravity of the bucket and the center of gravity of the handle, $\mathrm{m}$.

The resistance of the breed to digging is determined by the formula [8]:

$$
N_{r}=\frac{k_{S} \cdot \mathrm{E}}{H_{p . s h} \cdot k_{l}}, \mathrm{~N}
$$

where $H_{p . s h}$ - is the height of the pressure shaft, m;

$k_{l}$ - coefficient of loosening of the rock, $k_{l}=1,2-1,3$. 
In the face pattern shown in Fig. 3, it can be seen that the excavator, until subunit 6 , works with horizontal scooping at a standing level. In this case, the volume of the rock, the working time of subunits $0-6$ and the filling factor of the excavator bucket is determined according to the table. 6 .

Table 6: Determination of technological parameters for working out of exit ledges

\begin{tabular}{|l|c|c|c|c|c|c|c|}
\hline \multicolumn{1}{|c|}{ Parameters } & $\begin{array}{c}\text { Calculationformula } \\
\mathrm{s}\end{array}$ & $\begin{array}{c}1- \\
\text { subunit }\end{array}$ & $\begin{array}{c}2- \\
\text { subunit }\end{array}$ & $\begin{array}{c}3- \\
\text { subunit }\end{array}$ & $\begin{array}{c}4- \\
\text { subunit }\end{array}$ & $\begin{array}{c}5- \\
\text { subunit }\end{array}$ & $\begin{array}{c}6- \\
\text { subunit }\end{array}$ \\
\hline $\begin{array}{l}\text { Rock volume of } \\
\text { one digging, } \mathrm{m}^{3}\end{array}$ & $\Delta V_{n}=(2 n-1) \Delta V_{1}$ & 1,5 & 4,5 & 7,5 & 10,5 & 13,5 & 16,5 \\
\hline $\begin{array}{l}\text { Sub block } \\
\text { processing time, } \mathrm{s}\end{array}$ & $\Delta t_{n}=\left(\mathrm{B}_{\mathrm{W}} / \mathrm{B}_{b}\right) t_{c}$ & 180 & 180 & 180 & 180 & 180 & 180 \\
\hline Bucket fill factor & $k_{f}=\left(\frac{\Delta V_{n}}{V_{b}}\right)$ & 0,09 & 0,27 & 0,45 & 0,64 & 0,82 & 1,00 \\
\hline
\end{tabular}

$* \mathrm{n}$ - is the separation queue of the excavator subunit; $\Delta \mathrm{V}_{1}$ - rock volume of the first subunit, $\mathrm{m}^{3} ; \mathrm{B}_{\mathrm{b}}$ - excavator bucket width, $\mathrm{m}$.

According to the data given in the table. 6, we establish the dependence of the fill factor of the bucket of the excavator on the removable volume of the subunit.

From fig. 4 shows that the excavator to subunit 6 works with horizontal scooping at a standing level and minimum bucket filling factors.

The working time of subunits $0-6$, taking into account the movement of the complex will be:

$$
t_{0-6}=6 \cdot t_{c} \cdot \frac{B_{W}}{B_{b}}+\frac{L_{0-6}}{L_{m}} \cdot t_{m}, \mathrm{~h}
$$

where $t_{m}$-the time of one movement of the complex, min. The average productivity of the complex when practicing subunits 0-6:

$$
Q_{S(0-6)}=\frac{60 \cdot V_{0-6}}{t_{0-6}}, \mathrm{~m}^{3} / \mathrm{h}
$$

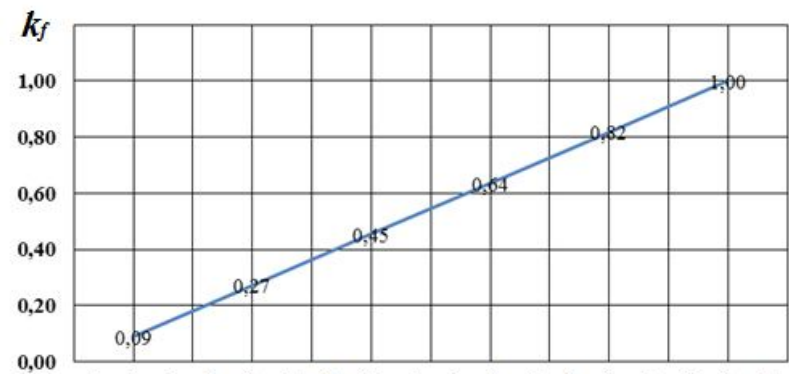

1-subunit 2-subunit 3-subunit 4-subunit 5-subunit 6-subunit

Figure 4: The dependence of the fill factor of the bucket of the excavator on the removable volume of the subunit

Starting from subunit 6 , the bucket filling ratio will be equal to 1 , while the bottomhole height will be $1.2 \mathrm{~m}$ and will be higher than the chip thickness. In this regard, the excavator will not be able to scoop in horizontal layers and will begin scooping along the radius of the handle with an allowable chip thickness.

In this case, it is necessary to determine the actual performance of the excavator, taking into account the conditions of the face. The effective operation of the excavator is determined by establishing the height of the digging. Therefore, the sufficient height of the digging of the excavator is determined from the conditions of filling its bucket when developing a ramp. The formula determines the bucket filling factor with the installed chip thickness:

$$
k_{f}=\frac{\mathrm{B}_{b} \mathrm{C}_{\max } l_{a}}{V_{b}}=\frac{\mathrm{B}_{b} S_{c S}}{V_{b}},
$$

where $l_{a}$ - is the arc of digging, $\mathrm{m}$; $S_{c . s .}$ - is the cross-sectional area of one scooping with a known chip thickness, $\mathrm{m}^{2}$.

For different bottom heights, we determine the fill factor of the excavator bucket according to the scheme shown in Fig. 5 . It can be seen from the diagram that with an increase in the bottom height, the length of the scooping arc increases and, accordingly, the volume of rock per scoop.

For a more accurate calculation of the face, we use the mathematical model for determining the area of the excavator's digging segment with the establishment of chip thickness (with radii scooping $\mathrm{R}_{1}$ and $\mathrm{R}_{2}$ ) (Figure 5).

To calculate the $\mathrm{OABC}$ area, we construct a rectangular coordinate system. We draw the $\mathrm{OX}$ axis through the segment $\mathrm{OA}$ and the $\mathrm{OY}$ axis at the point $\mathrm{O}$ perpendicular to the OX axis. Then the desired region of OABS is limited by lines

or

$$
\begin{gathered}
x^{2}+(y-8,5)^{2}=8,5^{2}, x^{2}+(y-8,5)^{2}=9,5^{2}, \\
y=0 y=a
\end{gathered}
$$

$$
\begin{gathered}
x=\sqrt{8,5^{2}-(y-8,5)^{2}}, x=\sqrt{9,5^{2}-(y-8,5)^{2}}, \\
0 \leq y \leq a .
\end{gathered}
$$

Then the desired area is calculated using the double integral:

$$
\begin{aligned}
& S=\iint_{O A B C} d x d y=\int_{0}^{\Delta h}\left[\int_{\sqrt{R_{1}-\left(y-R_{1}\right)^{2}}}^{\sqrt{R_{2}-\left(y-R_{1}\right)^{2}}} d x\right] d y= \\
& =\int_{0}^{a}\left[\left.x\right|^{\sqrt{R_{2}^{2}-\left(y-R_{1}\right)^{2}}}\right] d y= \\
& =\int_{0}^{\Delta h}\left(\sqrt{R_{2}{ }^{2}-\left(y-R_{1}\right)^{2}}-\sqrt{R_{1}{ }^{2}-\left(y-R_{1}\right)^{2}}\right) d y= \\
& =\left|\begin{array}{c}
t=y-R_{1}, d t=d y \\
y=0, t=-R_{1} \\
y=\Delta h, t=\Delta h-R_{1}
\end{array}\right|=
\end{aligned}
$$




$$
\begin{gathered}
=\int_{-R_{1}}^{\Delta h-R_{1}}\left[\sqrt{R_{2}{ }^{2}-t^{2}}-\sqrt{R_{1}{ }^{2}-t^{2}}\right] d t=\int_{-R_{1}}^{\Delta h-R_{1}} \sqrt{R_{2}{ }^{2}-t^{2}} d t \\
-\int_{-R_{1}}^{\Delta h-R_{1}} \sqrt{R_{1}{ }^{2}-t^{2}} d t= \\
=\left.\frac{1}{2}\left(t \sqrt{R_{2}{ }^{2}-t^{2}}+R_{2}{ }^{2} \arcsin \frac{t}{R_{2}}\right)\right|_{0} ^{\Delta h} \\
=\left.\frac{1}{2}\left(t \sqrt{R_{1}{ }^{2}-t^{2}}+R_{1}{ }^{2} \arcsin \frac{t}{R_{1}}\right)\right|_{0} ^{\Delta h}= \\
\left.+R_{1} \sqrt{R_{2}{ }^{2}-R_{1}{ }^{2}}+R_{2}{ }^{2} \arcsin \frac{R_{1}}{R_{2}}\right)- \\
-\frac{1}{2}\left(\left(\Delta h-R_{1}\right) \sqrt{R_{2}{ }^{2}-\left(\Delta h-R_{1}\right)^{2}}+R_{2}{ }^{2} \arcsin \frac{\Delta h-R_{1}}{R_{2}}\right. \\
\left.+R_{1}{ }^{2} \frac{\pi}{2}\right)=
\end{gathered}
$$

$$
\begin{gathered}
=\frac{1}{2}\left(\left(\Delta h-R_{1}\right) \sqrt{R_{2}{ }^{2}-\left(\Delta h-R_{1}\right)^{2}}+R_{2}{ }^{2} \arcsin \frac{\Delta h-R_{1}}{R_{2}}\right. \\
\left.+R_{1} \sqrt{{R_{2}}^{2}-R_{1}{ }^{2}}+R_{2}{ }^{2} \arcsin \frac{R_{1}}{R_{2}}\right)- \\
-\frac{1}{2}\left(\left(\Delta h-R_{1}\right) \sqrt{R_{1}{ }^{2}-\left(\Delta h-R_{1}\right)^{2}}+R_{1}{ }^{2} \arcsin \frac{\Delta h-R_{1}}{R_{1}}+\right. \\
\left.R_{1}{ }^{2} \frac{\pi}{2}\right)
\end{gathered}
$$

\section{RESULTS}

By asking several values $\Delta$ hand $\mathrm{C}_{\max }$, we find the corresponding values of the OABS area $\left(\mathrm{S}_{\mathrm{c.s}}\right)$ and, accordingly, the removed rock volume $(V n)$, as well as the bucket, fill factor $k_{f}$. According to the graph of the function $k_{f}=f(\Delta h)$, determine the specific values of the filling coefficient of the excavator bucket Figure 6.

In the table 7 shows the results of calculations to determine the fill factor of the bucket of the excavator during the development of the exit ledge.

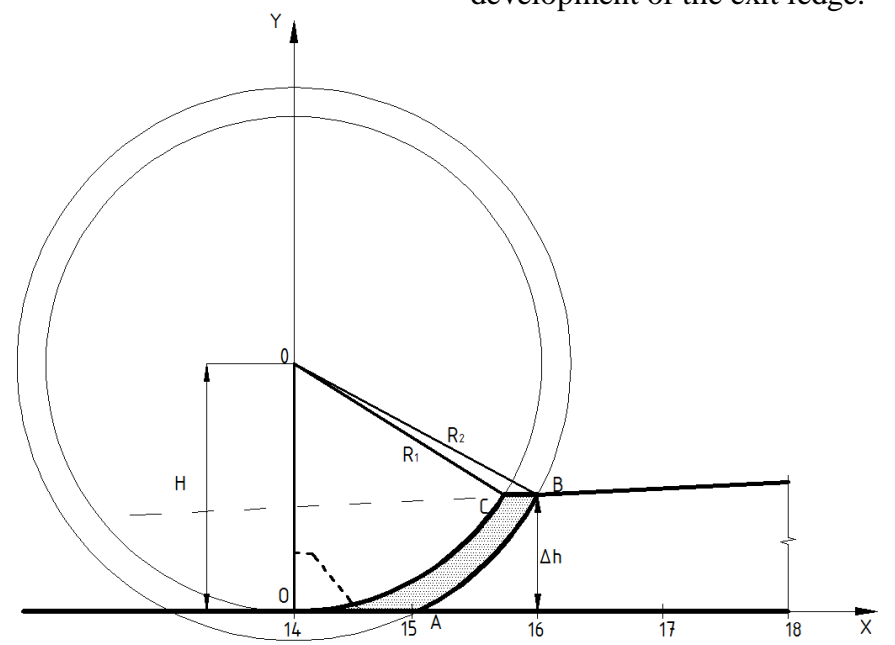

Figure 5: Scheme for determining the area of the excavator's digging segment when developing an exit ledge with establishing chip thickness: $\mathrm{H}$ - excavator pressure shaft height.

Table 7: The results of the calculation of determining the fill factor of the bucket of the excavator during the development of the exit ledge

\begin{tabular}{|c|c|c|c|c|c|c|c|}
\hline$\Delta \boldsymbol{h}, \mathbf{m}$ & $\mathbf{C}_{\mathbf{m a x}}, \mathbf{m}$ & $\mathbf{R}_{\mathbf{1}}, \mathbf{m}$ & $\mathbf{R}_{\mathbf{2}}, \mathbf{m}$ & $\boldsymbol{S}_{\boldsymbol{c . s} .}, \mathbf{m}^{\mathbf{2}}$ & $\mathbf{V}_{\mathbf{s}}, \mathbf{m}^{3}$ & $\mathbf{V}_{\mathbf{b}}, \mathbf{m}^{3}$ & $\boldsymbol{k}_{\boldsymbol{f}}$ \\
\hline 1,0 & 1 & 9,5 & 8,5 & 2,42 & 6,06 & 16,5 & 0,37 \\
\hline 1,5 & 1 & 9,5 & 8,5 & 3,28 & 8,19 & 16,5 & 0,50 \\
\hline 2,0 & 1 & 9,5 & 8,5 & 4,04 & 10,09 & 16,5 & 0,61 \\
\hline 2,5 & 1 & 9,5 & 8,5 & 4,74 & 11,84 & 16,5 & 0,72 \\
\hline 3,0 & 1 & 9,5 & 8,5 & 5,39 & 13,47 & 16,5 & 0,82 \\
\hline 3,5 & 1 & 9,5 & 8,5 & 6,00 & 15,01 & 16,5 & 0,91 \\
\hline 4,0 & 1 & 9,5 & 8,5 & 6,59 & 16,48 & 16,5 & 1,00 \\
\hline 4,5 & 1 & 9,5 & 8,5 & 7,16 & 17,90 & 16,5 & 1,08 \\
\hline 5,0 & 1 & 9,5 & 8,5 & 7,71 & 19,28 & 16,5 & 1,17 \\
\hline
\end{tabular}

From the table 7 it is seen that to fill the excavator bucket with one scooping, the required bottomhole height will be $\Delta h=4 \mathrm{~m}$. This means that until the subunit 20, the excavator will operate with lower productivity. After the 20th subunit, the excavator will begin to work as usual. 
The expression determines the processing time of the subblock $(n-(n+1))$ :

$$
t_{(n-(n+1)}=\left(\frac{L_{(n-(n+1)}}{C_{c h}} \cdot t_{c}\right) \cdot \frac{\mathrm{B}_{w}}{\mathrm{~B}_{b}}+\frac{L_{(n-(n+1)}}{L_{m}} \cdot t_{m}, \mathrm{~h}
$$

where $C_{c h}$ - the thickness of the removed chips, m.

The expression determines the volume of the subblock (n$(\mathrm{n}+1))$ :

$$
\begin{aligned}
V_{(n-(n+1)}= & \left(\frac{L_{n-(n+1)} \cdot\left(\Delta h_{(n+1)}-\Delta h_{n}\right)}{2} \cdot B_{w}\right)+ \\
& \left(L_{n-(n+1)} \cdot \Delta h_{n} \cdot B_{w}\right), \mathrm{m}^{3}(13)
\end{aligned}
$$

The average productivity of the sub-block mining complex $(n-(n+1))$ :

$$
Q_{a v(n-(n+1)}=\frac{V_{n-(n+1)}}{t_{n-(n+1)}}, \mathrm{m}^{3} / \mathrm{h}
$$

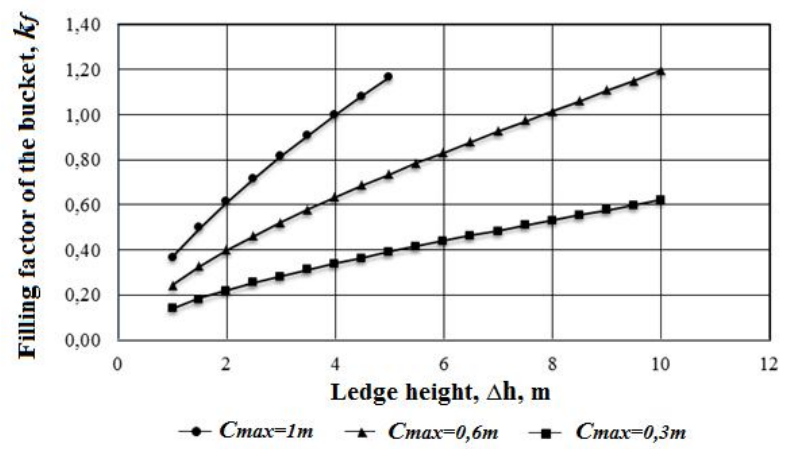

Figure 6. The dependence of the filling factor of the bucket of the excavator on the height of the bottom at different chip thickness

\section{CONCLUSION}

Thus, a methodology and mathematical model have been developed for determining the working time and productivity of the mobile crushing, reloading and conveyor complexes when working out an inclined exit ledgeю

\section{REFERENCES}

1. Nasirov U.F., ZairovSh.Sh., Annakulov T.J.«The use of cyclic-flow technology schemes with mobile and mobile crushing and reloading complexes in open cast mining//Scientific, technical and industrial journal"Mining journal of Uzbekistan". Navoi, 2019 № 2 . - pp. $36 \div 39$.

2. ZairovSh.Sh., Annakulov T.J., Kuvondikov O.A., Sharipov L.O. «Calculation of technological parameters of equipment sets for mobile crushing, reloading and conveyor complexes//Scientific, technical and industrial journal"Mining journal of Uzbekistan". Navoi, 2019 № 3. - pp. $29 \div 34$.

3. Faul A.A. «The definition of parameters and indicators of opencast mining of deposits of nometallic building materials using mobile crushing complexes» //Dissertation of the candidate of science. - St. Petersburg, 2012.-193p.

4. Annakulov T.J.« Improvement of cyclic-flow technology development overburden
cutAngrenwith mobile complexes»//«European Applied Sciences» ORT Publishing. -Stuttgart, Germany, 2015. - №6. - pp. 58-60.

5. Annakulov T.J. «Intensification of cyclic and flow technology with the use of mobile complexes in coal fields»// Dissertation of the doctor of philosophy (PhD) on technical sciences. -Navoiy, 2019. - 120 p.

6. DombrovskiyN.G. «Excavators. General issues of theory, design, research and application». - M.: Mechanical Engineering, 1969 .- 319 p.

7. Frolov K.V., Ksenevich I.P., Volkov L.A., Karasev G.N. andother.«Encyclopedia of mechanical engineering». Vol.IV - M.: Mechanical Engineering, 2005 .- $736 \mathrm{p}$.

8. PoderniR.Yu. «Mechanical equipment quarries». Textbook for high schools. - M.: Publishing House of the Moscow State Mining University, 2003 .- 606 p.

9. Usmanov N.S., Soy I.V., Irkabayev U.U., Nasriddinov I.X., Annakulov T.J. «Experience in introducing cyclic-flow technology at the overburden complex of open pitAngren»//Scientific, technical and industrial journal"Mining journal of Uzbekistan". Navoi, 2015 №1. - pp. $82 \div 86$.

10. Annakulov T.J., ZairovSh.Sh.,Kuvandikov O.A. «Justification, selection and calculation of technological parameters of equipment kits of mobile crushing-reloading-conveyor complexes // International Journal Of Advanced Research in Science, Engineering and Technology».- India: National Institute of Science Communication and Information Resources, 2019, Fevruiary. - Vol.6. Issue 2. - pp. 8072-8079.

11. Annakulov T.J. «Development of technological schemes for open-pit mining using mobile complexes»//Materials of the XXIV International Scientific and Practical Conference on the theme: "Innovation-2019". - Tashkent: Tashkent State Technical University, 2019 .-p.p.192-194.

12. Mohammad Reza Tavakoli Mohammadi, Seyed Ahmad Hashemi, Farhad Moosakazemi. «Review of the in-pit crushing and conveying (IPCC) system and its case study incopperindustry. https://www.researchgate.net/publication/270888181. 